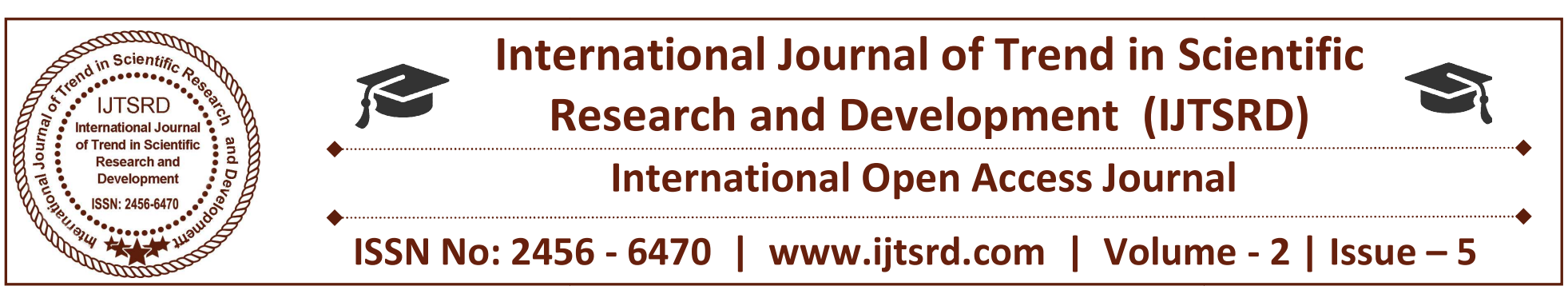

\title{
Rethinking Peer Apprenticeship Through the Acquisition of Compliance Skills in Middle Childhood: Implications for Cultural Socialisation in Cameroon
}

\author{
Dr. Kumncho Eveline Neh \\ Department of Educational Psychology, Faculty of Education, University of Buea, Cameroon
}

\section{ABSTRACT}

This empirical article reassessed peer apprenticeship as a cultural construct and how acquisition of compliance skills in Middle Childhood (6-11 Years) is guided by this construct. The main objective of this study was to investigate peer apprenticeship and the acquisition of compliance skills in middle childhood children. The purposive sampling technique was used to elect 75 participants that made up the sample of the study. The study employed a combination of primary and secondary data collection techniques. Primary techniques included field observations, and administration of questionnaire. The survey design was used to sample parents' and teachers' views while the quasi-experimental design was used for pupils. Analysis of findings revealed that; Peer apprenticeship influences the acquisition of compliance skills in children. This is evidence because the experimental group showed a significant improvement between the pre-test and post-test $(\mathrm{P}<0.001)$ than the control group $(\mathrm{P}=1.000)$. The results also revealed that with instructions from teachers, children teach and uphold responsibility training skills, cultural values and practices. Some recommendations for successful peer interaction were included: teachers and education administrators should create school and classroom environments that facilitate children's interactions by encouraging cooperative play, collaborative learning and peer appropriate behaviour; cooperative learning should be taken into consideration where children are put in groups to learn; and school administrators should implement social training skills in the school curriculum.

Keywords: Peer Apprenticeship, Acquisition Of Compliance Skills, Middle Childhood. Cultural Socialization

\section{INTRODUCTION}

Cultural socialization has long interested behavioral and social scientists, but recent advances in theory and methodology have allowed researchers to construct new and more powerful theoretical frameworks for conceptualizing the complex ways in which children interact with their environments during the course of development. Studies of childhood socialization in the classic tradition of cross-cultural research were static in their approach to analyzing underlying processes because of limitations in the theories and methods available at the time they were conducted. Many studies, for example, involved straightforward associations or comparisons of levels of parental socialization pressure (the antecedent condition) with children's social or cognitive behavior (the consequent condition). In contrast, using new theoretical and methodological tools, researchers today can go beyond testing predictions about how differences in childhood environments may predict group differences in some kind of child characteristic and instead consider dynamic and transactional childenvironment relations. For instance, current researchers have employed theoretical frameworks from social-cognitive development, Vygotskian psychology, and cultural psychology to characterize the children and their contexts in reframed ways and to highlight such themes as self-socialization and guided participation in cultural socialization.

The humanity of children and their peers has fascinated developmental psychologists for more than three decades (Hartup, 1986), and studying it over this period has given a number of interesting and important insights. As a matter of fact, peer interactions change in systematic ways as children's ages and peers have different functions in children's 
lives at different ages (Rubin, Chen and Buskirk, 2005). What happens in children's friendship relations affects development and functioning in probably every other aspect of children's lives, including the family, the community, and school. What goes on in these settings in turn affects children's operation in their groups. Thus, children's interactions with their peers and friends are connected with numerous aspects of development and adjustment including their achievement in school (Gifford-Smith and Brownell, 2008).

An early view of the development of adaptive and maladaptive behaviours during childhood suggested that such outcomes stemmed largely, if not mostly, from the quality of the child's relation with his or her parents and not from the socialization practices that the parents demonstrated Bowlby, (1958). Without denying the sincerity of these claims, it is nevertheless the case that adjustment and maladjustment in childhood stem from a wide variety of sources including genetic and biological underpinning and social influences other than parents. For example, children spend much of their time, both in and out of home, relating to and interacting with many others of potential influences. The significant others include their teachers, siblings, out of home caregivers and peers. It is this last group, children's peers, is the focus of this study. Beyond peers' function as companions in leisure activities they serve as sources of instrumental and emotional support, help a child formulate values and beliefs, and oversee a child's adherence to behavioural norms of the peer culture and broader society (as stated by Rubin et al., 2005)

They further said that, experiences with peers constitute an important developmental context for children and these experiences occur on several different levels: general interactions with peers, friendships, in- groups. As these children interact they develop different competences such as, social, intellectual, emotional and moral. The development of children's social competences is the core of this study. Social competence reflects a child's capacity to engage successfully with peers at different levels. The context of social interaction which involves cooperative play, peer apprenticeship, peer collaboration and peer acceptance among children provides precious harmonizing and unique opportunities for the acquisition of social competencies.
Children's Increasingly Active Role in the Socialization Process

The second principle about peer relationships in cultural context is that both across and within cultural communities, children's active role in the socialization process becomes increasingly evident as they grow older. Children's own characteristics, based on their gender, age, and unique characteristics such as their temperaments, personalities, and interests, become ever more important in determining their behavior, response patterns, and choices of preferred playmates, settings, and activities. Children are active protagonists in their own development in ways that become ever more influential as their personal characteristics become more elaborated and their scope of control increases. This principle is based directly on the theory about gene-environment effects, which states that active and evocative forms of gene environment interactions become more prominent as children grow older, whereas the passive form becomes secondary. The very environments in which children participate are both influenced by and reflective of their genetic predispositions; indeed, children become actively more able to choose their contexts and manage their experiences.

Studies examining how children become engaged in their own activities show how children play an agentic role in their own socialization experiences. For instance, Tudge and Hogan (2005) have developed an observational methodology that includes recording not only the types of activities children engage in, but also the extent to which they are engaged, how they became involved, and their role in initiating others' participation. They provide empirical data suggesting that children are active agents in their participation in various contexts and activities and are by no means passively experiencing settings and events structured and chosen by adult figures. Children are indeed able to choose to participate in various activities, initiate new ones, and encourage the participation of others, including adult caregivers (Tudge et al., 2000; Tudge et al., 1999). Moreover, active engagement in activities appears to be related to perceived competence over the years and varies within cultures along the lines of social class.

This ability to engage in one's own choices and to play an active role in one's experiences also increases with age. As such, children's own preferences and individual proclivities in peer interaction become more evident. This is reflected in the increasing 
variability in children's choice of companions. For instance, in studies of U.S. children, where most of this research has been conducted, friendships evolve dramatically between early and middle childhood (Rubin, Bukowski, \& Parker, 1998), likely reflecting both societal experiences at those ages, as well as developmental changes that they are undergoing. Older children spend more time with peers (Feiring \& Lewis, 1989) and ambit more importance to peer relationships than do younger children (Berndt \& Hoyle, 1985; Buhrmester \& Furman, 1987; Pitcher \& Schultz, 1983). Older children's friendships also tend to be more stable (Berndt \& Hoyle, 1985), and, at least for girls, more intimate (Buhrmester \& Furman, 1987). Lastly, children's conceptions of friendship evolve to focus on more affective, motivational, and pro-social intentions and less on external characteristics (Furman \& Bierman, 1983). Thus, with age, children's friendships become more delineated and stable, and conceptions of friendship become more sophisticated.

With age, children are more able to choose with whom to interact and, as such, children's own preferences become emergent. One of the most substantiated and cross-culturally robust patterns in peer relationships is the tendency to spend time with same-gender companions (Belle, 1989; Feiring \& Lewis, 1987; Pitcher \& Schultz, 1983). In fact, researchers have found the same-gender friendship pattern in studies using several methodologies, including observations of children's interactions (Boyatzis, Mallis, \& Leon, 1999; Harkness \& Super, 1985; nominations of friends (Graham et al., 1998), and socio-metric ratings of peers (Lockheed, 1986). Children as young as 33 months display the samegender friendship pattern (Jacklin \& Maccoby, 1978). This pattern appears to increase in intensity with age until middle childhood (Belle, 1989; Maccoby, 1988, 1990).

\section{The role of peer apprenticeship and friendships in development}

Having friends is a fundamental concern in the lives of children. Parker and Asher, (1993) indicates that mutual, constructive peer relations are closely associated with positive developmental outcomes and can have beneficial effects on adult life. Research has shown that friendships enhance a child's social and psychological development. For example, children with friends show different reasoning patterns about social events and behave differently than children who are friendless. Friendship is an important facilitator of emotional responsiveness in children and may increase demonstrated pro-social behaviours. Also, childhood friendships can act as a "buffer" against psychiatric disorders that might arise later in life. Friendship provides a unique learning context wherein children are able to develop and to practice socially competent behaviours. This is because they have more opportunities to practice social competence, and to build healthy relations with peers (Gifford-Smith and Brownell, 2003). As children improve their ability to understand the emotions of others, they build increasingly mature friendships and strengthen their interpersonal and learning-related skills. Children and adolescents who have difficulty empathizing or self-regulating have few positive social interactions and are likely to be rejected or neglected by peers, this can significantly impact social well-being and academic outcomes (emphasized by Rubin et al., 2006).

Friendship also provides children with intimacy and support (Howes, 1996), which have their own distinctive contributions to childhood development. Hartup and Stevens (1997) outline three positive effects that are offered uniquely by the context of friendship. First, having friends allows children to learn necessary social skills and to continually develop their social behaviour repertoire. Also, friendship provides unique cognitive resources to the parties involved. Finally, emotional needs can be met through the bonds of childhood friendship. Not only has the positive psychological impact of friendship been documented in research, but theorists have also acknowledged the essential nature of friendship. Sullivan's (1953) interpersonal theory of development states that friendship provides children with a unique opportunity to satisfy their needs for intimacy and reciprocity. According to this theoretical perspective, friendship is a necessary condition for healthy development and the acquisition of social skills. It teaches children to identify with other's thoughts and feelings and to act altruistically (McGuire and Weiisz, 1982). In this sense, peer relations create a psychological context that encourages cooperation and facilitates conflict resolution (as mentioned by Gifford-Smith and Brownell, 2003).

Children learn ways in which, their cooperation is welcomed, and how they can take part for what they want (Elkin and Handel, 1978). Furthermore, they start imitating their peers at early ages, spending lots 
of time watching what they do, even though, children between the ages of two to three years, are more likely to be self-centred and are not interested in others feelings'. "As children get older they learn how to share and take turns, and start to make friends with peers within their social groups, and in social situations" (Piaget, 1932), Equally as children become aware of the world around them, in particular how everything in it relates to them, they learn to make friends, and start communicating with their peers, both within their own age group and older. 'Children move in peer environments offering opportunities for support, and develop an understanding of others' finding ways to learn from and enjoy the company of one another (Essays, 2013).

He further echoed Shaffer (1996) words that children's friendships with others build upon two individual interactions based on trust respect and security. Shaffer further suggests that 'sociability plays a key part in the social development of children and that this depends on the skills children acquire during the first years of life'. Therefore, children who show negative behaviour towards their peers will find it difficult to make friends. 'Peer difficulties in the early years are predictors of future problems, such as, feelings of loneliness, aggression anxiety and depression.

Peer relations are not always positive in their impact on children's sense of self, but successful friendships can enhance self-esteem and lay the foundations for future encounters with others. Friendships is most successful when it is mutually conceived and created, and reciprocated (Dunn, 2004). Even young children seek to develop interpersonal relations and affiliations with each other and with members of their peer group Young children value the same friendship dimensions of intimacy, support, trust and mutuality as do older children and adults. Of interest, however, is the extent to which these significant relations also reflect a process whereby change in competencies occurs as a result of friend influence. For instance, simply having a close friend might have developmental significance for healthy adjustment over time. Individuals also might adopt or develop specific behavioural styles or interests because they are considered to be desirable characteristics of their close friends (as mentioned by Rubin et al., 2005).

Friendship influence often focus on the likelihood that positive emotional attachments to friends promote healthy psychological functioning; feelings of relatedness and belonging that result from having friends are believed to contribute directly to positive feelings of self-worth and self-esteem. In turn, these levels of emotional well-being are believed to contribute to adaptive functioning in social as well as academic domains. Substantial evidence based on children at all ages supports this perspective (Wentzel, 2005). Bandura posit an observational learning explanation of influence in which a friend models behaviour that is subsequently adopted by a child who observes the behaviour (Wetzel, 2005). Empirical findings provide support for this position in that children have the opportunity to observe their friends' behaviour with greater frequency than non-friends' behaviour. In addition, behaviour that is learned by observing others is likely to be enacted to the extent that an individual is motivated to do so (Bandura, 1986). Therefore, a child's behaviour might become more similar to a friend's behaviour because of a change in underlying motivational processes such as goals and self-concept.

Essays, (2013) said that, research on motivation documents that, peers serve as powerful models that influence the development of academic self-efficacy, especially when children observe similar peers who demonstrate successful ways to cope with failure. These modelling effects are especially likely to occur when children are friends, although children who have higher achieving friends tend to have lower levels of self-efficacy than those with lower-achieving friends.

Theorists have proposed that positive interactions with peers contribute directly to intellectual development and functioning. For example, Piaget (1965) argued that mutual discussion, perspective taking, and conflict resolution with peers can motivate the accommodation of new and more sophisticated approaches to intellectual problem solving. Research has supported his position in that active discussion, problem solving, and elaborative feedback among peers are associated with advances in a range of cognitive competencies, including problem-solving skills, conceptual understanding, and meta-cognitive reasoning in samples ranging from preschool to high school. Of relevance for understanding the influence of friends on cognitive development is research indicating that interactions with friends rather than non-friends tend to yield more predictable cognitive advances, presumably because friends have wellestablished interaction patterns and are sensitive to each other's interests and needs (Essays,2013). 


\section{Peer apprenticeship and the development of compliance skills}

Garton and Pratt (2001) conducted a study to investigate the effect of peer apprenticeship on children's compliance skills. The participants were 100 Year 2 children (aged between 6 and 7 years), from schools in high socio-economic areas, who individually completed a pre-test and post-test comprising a block sorting task. The study was an experimental study where during the experimental phase; children completed a card sorting activity, either individually or in same-gender dyads. The dyads consisted of same or different ability children who operated under either a 'talk' or 'no-talk' condition. Pairs in each of the experimental conditions were then randomly divided into two levels of interaction ('talk' where children were required to explain the sort for their partner to carry out, or 'no talk' where talking was discouraged and children carried out their own sort). They were given precise instructions according to the experimental condition to which they were assigned (Smith, 2010).

The extent to which the instructions were obeyed was monitored but no experimenter intervention was required as there were no obvious deviations (such as no talk pairs talking), nor any obvious variation between dyads in either condition. The experimental task consisted of children working collaboratively in pairs to sort the clothing cards in many different ways as possible to a maximum of 14 . Data was analyzed quantitatively and it was founded that children who collaborated collectively obtained a significantly higher number of correct sorts than children who worked individually. However, post-testing indicated that only those children of lower sorting ability who collaborated with higher sorting ability peers showed a significant improvement in sorting ability from pretest scores. In addition, it was found that when analysis was limited to this particular group, only those children who were required to explain the sort for their partner to carry out improved significantly from pre- to post-test (Smith, 2010).

Also Smith, (2010) carried out a study on the role of peers in children's learning. The study was to explore how children work together collaboratively as peer tutors within early childhood settings. Explicitly, the study investigated how children work together, collaborate and act as peer tutors. The research was structured within a post-positivist paradigm and a qualitative case study approach was adopted. The data collection methods included observations during children's play, and informal conversations with the children. Interviews were conducted with teachers. The data collected from participants was analyzed using constant comparative analysis to identify the emerging themes. Rogoff's (1998) plane was used to provide a further tool for analysis of peer learning.

The results gathered from this study were that, young children are capable peer tutors who use a variety of strategies to work together successfully with their peers. The evidence gathered, from this study highlighted the need for teachers to create empowering environments where children can direct their learning alongside their peers. Another important finding was that routines impacted negatively on opportunities for sustained collaborative play. The study revealed the need for teachers to adopt a responsive teaching presence, interpreting their role in response to children's efforts to engage in collaborative endeavour. It is argued that teachers need to position children as experts who are capable of sharing their expertise with their peers to advance their understanding. This requires teachers to provide meaningful opportunities for children to take on teaching roles with their peers. Though the above studies were conducted in Australia and New Zealand respectively, they have contributions to make to the present study.

Furthermore, Garton and Pratt (2001) and JohnsonPynn and Nisbet (2000) carried out a study in New Zealand, on children's apprenticeship strategies .The children in these studies were typically paired together and the environment was configured to specifically support opportunities for children to tutor each other. The researchers made use of quantitative methods to investigate peer tutoring strategies as they worked together using blocks. Twenty eight pairs of three to five-year-old children in Johnson-Pynn and Nisbet's (2002) study constructed a house out of blocks. The frequency of both the verbal and nonverbal aid provided by the expert (those with task experience) to the novice (those children without task experience) was scored. The findings provided evidence of children as young as three assisting their peers spontaneously, making statements which indicated their willingness to "teach" their peers. The experts provided a variety of forms of assistance to the novices, including strategies to approach the task and statements to motivate the novice. As children work together, they challenge each other by offering 
alternative viewpoints which lead to the trying out of new ideas; a resolution of the conflict caused by contradictory views results in re-equilibration and new understanding. The importance of this process is described by Flavell who states that "according to Piaget, states of cognitive conflict and disequilibrium impel the child to make cognitive progress" (Flavell, 1977). The researchers were surprised by the capabilities of the preschool age children, concluding that they can capably assume the role of a peer tutor. This study is similar to the present study in that the present study has used the variable peer apprenticeship to see how peers tutor or teach other peers and how this enhances compliance skills (as mentioned by Smith, 2010).

The above findings are consistent with Vygotksy's beliefs. Vygotsky (1978) argued that collaboration is more beneficial in peer interaction since children acquire cognitive skills while solving problems interactively with more capable peers. He also believes that children were actively involved in the process. As children participate in meaningful experiences with more knowledgeable others, they are supported by their peers with whom they develop shared understandings and there are opportunities for children to internalize the language The present study also makes use of Vygotsky's framework. It is being theorised as the main framework for the study.

In terms of methodology, the present study borrows from Garton and Pratt (2001) study by using experimental method and the aspect of quantitative method of data analysis. While the qualitative method of data analysis is lend from Smith, (2010). The use of observations, interviews with teachers and conversations with children proved to be an effective means of exploring the nature of peer learning in an early childhood setting. However, the observations were limited in that they only captured the morning sessions. Longer periods of observation time could have been used to identify if children passed on knowledge to other children. The use of constant comparative analysis (LeCompte and Preissle, 1993) to identify emerging themes and Rogoff's (1998) planes of analysis in this helped to ensure confidence in data interpretation (as cited by Smith 2010). He also conducted interviews with teachers to gain an inside of teacher's ideas about peer learning. However, they should have been interviews also with the children or focus group discussions with the children, to get their idea about learning with their peers. The present study conducted interviews to get children's ideas about peer learning and also to compare their ideas with those of parents and teachers.

Garton and Pratt (2001) research uses 100 children as sample size while the present study made use of 36 children but goes further to use teachers and parents. More so, the age brackets in Garton Pratt study is 6- 7 years and the present study extends to 11 years, that is, 6-11 years. Though the above studies were carried out in different countries as compared to this study, they have a meeting point (peer learning,-peer collaboration and this gives an opportunity to the research to compare the findings gathered from the present study to that of Garton and Pratt (2001), and Smith, (2010).

\section{METHODOLOGY}

\section{Research Designs}

To answer the objective of this study and propose a guideline that generalised the implementation of the findings, the quasi experimental design using exposure and evaluative methods were used. The quasi experimental design, specifically, the Pre-Post Test Design with Non-Randomized Experimental and control Groups were used for the current study.

\section{Sample and sampling Technique}

Table: 1 Number of students sampled per school

\begin{tabular}{|c|c|c|}
\hline Name of school & Frequency & Percent \\
\hline C. B. C Great-soppo & 12 & 33.3 \\
\hline G. S Bonakanda & 12 & 33.3 \\
\hline G. P. S Molyko II & 12 & 33.3 \\
\hline Total & 36 & 100,0 \\
\hline
\end{tabular}

The purposive sampling technique was adopted to select pupils for the study. Schools with moderate classroom sizes, that is, at most 30 pupils per classroom were first identified. Among those schools, one was sampled in each locality. A sample of 36 pupils was used; 12 pupils from each school, the 36 selected pupils were in class 3 in their respective schools. The children who took part in the study were of middle childhood (6-11) years old. Out of the 36 children involved in the study, 18 of them were in the experimental group and 18 of them in the control group, with weight of $(50.0 \%)$ respectively. A greater majority of the children were between 7 years and 8 years of age $34(94.4 \%)$. Just one child $(2.8 \%)$ was 6 years old and another one 9 years old $(2.8 \%)$. 
International Journal of Trend in Scientific Research and Development (IJTSRD) ISSN: 2456-6470 A reliability test was used to calculate the internal consistency of the instrument.

Table: 2 Reliability

\begin{tabular}{|c|c|c|c|c|}
\hline Test & Cronbach's Alpha & Variance & Covariance & $\mathbf{N}$ \\
\hline Pre-test experimental group & 0.320 & 0.026 & 0.012 & 18 \\
\hline First formative evaluation experimental group only & 0.746 & 0.028 & 0.008 & 18 \\
\hline Second formative evaluation experimental group only & 0.901 & 0.018 & 0.008 & 18 \\
\hline Post-test experimental group & 0.847 & 0.011 & 0.008 & 18 \\
\hline Pre-test control group & 0.470 & 0.030 & 0.013 & 18 \\
\hline Post-test control group & 0.668 & 0.034 & 0.009 & 18 \\
\hline Parents' questionnaire experimental group & 0.938 & 0.147 & 0.077 & 18 \\
\hline Parents' questionnaire control group & 0.918 & 0.096 & 0.079 & 18 \\
\hline
\end{tabular}

In the experimental group, it was observed an increased in Alpha from the pre-test to the second formative evaluation and post-test. As for the variance, in the experimental and the control groups, it was close to 0 indicating that the children had almost the same level of deficiency at pre-test and almost the same level of skill at post-test. The Covariance are all positive indicating that the trend of responses among the indicators within conceptual components follow the same pattern, which another added-value to the consistency of responses.

From parental perspective, variance value close to 0 also indicates that children at home portrayed almost the same level of skill.

\section{Results}

Ho: Peer apprenticeship does not significantly influence the acquisition of compliance skills in children.

H1: Peer apprenticeship significantly influences the acquisition of compliance skills in children.

Table 3: pre-test assessment for compliance skills (experimental group)

\begin{tabular}{|c|c|c|c|c|c|c|c|c|}
\hline Compliance skills & Always & $\begin{array}{l}\text { Most of } \\
\text { the time }\end{array}$ & $\begin{array}{l}\text { Some } \\
\text { times }\end{array}$ & Rarely & Never & \multicolumn{2}{|c|}{ Collapse } & $\mathbf{N}$ \\
\hline Experimental group & 8 & rieltor & 11061 & EItIIIC & $2=$ & Present & Absent & \\
\hline $\begin{array}{l}\text { I take to instructions without } \\
\text { complaining }\end{array}$ & $\begin{array}{c}0 \\
(0.0 \%) \\
\end{array}$ & $\begin{array}{c}0 \\
(0.0 \%)\end{array}$ & $(38.9 \%)$ & $\begin{array}{c}9 \\
(50.0 \%)\end{array}$ & $\begin{array}{c}2 \\
(11.1 \%) \\
\end{array}$ & $\begin{array}{c}7 \\
(38.9 \%) \\
\end{array}$ & $\begin{array}{c}11 \\
(61.1 \%) \\
\end{array}$ & 18 \\
\hline $\begin{array}{l}\text { I do my ho } \\
\text { beins }\end{array}$ & $\begin{array}{c}0 \\
(0.0 \%) \\
\end{array}$ & $\begin{array}{c}0 V \\
(0.0 \%)\end{array}$ & $\begin{array}{l}07 n \text { (1) } \\
(38.9 \%)\end{array}$ & $\begin{array}{l}10 \\
(55.6 \%) \\
\end{array}$ & $\begin{array}{c}1 \\
(5.6 \%) \\
\end{array}$ & $\begin{array}{c}7 \\
(38.9 \%)\end{array}$ & $\begin{array}{c}11 \\
(61.1 \%) \\
\end{array}$ & 18 \\
\hline $\begin{array}{r}\text { I listen } \\
\mathrm{di}\end{array}$ & $\begin{array}{c}0 \\
(0.0 \%) \\
\end{array}$ & $\begin{array}{c}0 \\
(0.0 \%)\end{array}$ & $\begin{array}{l}6 \\
(33.3 \%) \\
\end{array}$ & $(011 \%)$ & $\begin{array}{c}1 \\
(5.6 \%) \\
\end{array}$ & $\begin{array}{c}6 \\
(33.3 \%) \\
\end{array}$ & $\begin{array}{c}12 \\
(66.7 \%)\end{array}$ & 18 \\
\hline $\begin{array}{r}\text { I complete an } \\
\text { me c }\end{array}$ & $\begin{array}{c}0 \\
(0.0 \%) \\
\end{array}$ & $\begin{array}{c}0 \\
(0.0 \%) \\
\end{array}$ & $\begin{array}{c}8 \\
(44.4 \%) \\
\end{array}$ & $\begin{array}{c}8 \\
(44.4 \%) \\
\end{array}$ & $\begin{array}{c}2 \\
(11.1 \%) \\
\end{array}$ & $\begin{array}{c}8 \\
(44.4 \%) \\
\end{array}$ & $\begin{array}{c}10 \\
(55.6 \%) \\
\end{array}$ & 18 \\
\hline $\begin{array}{r}\text { I complet } \\
\text { other } \\
\text { in }\end{array}$ & $\%)$ & 8 & $(38.9 \%)$ & $\begin{array}{c}9 \\
(50.0 \%) \\
\end{array}$ & $x^{2}+1$ & $\begin{array}{c}7 \\
(38.9 \%)\end{array}$ & $\begin{array}{c}11 \\
(61.1 \%)\end{array}$ & 18 \\
\hline $\begin{array}{r}\text { I cut off } 1 \\
\text { by }\end{array}$ & $\begin{array}{c}0 \\
(0.0 \%) \\
\end{array}$ & $\begin{array}{c}0 \\
(0.0 \%) \\
\end{array}$ & $(5.6 \%)$ & $\begin{array}{c}15 \\
(83.3 \%)\end{array}$ & $\begin{array}{c}2 \\
(11.1 \%) \\
\end{array}$ & $\begin{array}{c}1 \\
(5.6 \%) \\
\end{array}$ & $\begin{array}{c}17 \\
(94.4 \%) \\
\end{array}$ & 18 \\
\hline $\begin{array}{r}\text { I play wi } \\
\text { ap }\end{array}$ & $\begin{array}{c}0 \\
(0.0 \%) \\
\end{array}$ & $\begin{array}{c}0 \\
(0.0 \%) \\
\end{array}$ & $\begin{array}{c}8 \\
(44.4 \%) \\
\end{array}$ & $\begin{array}{c}9 \\
(50.0 \%) \\
\end{array}$ & $\begin{array}{c}1 \\
(5.6 \%) \\
\end{array}$ & $\begin{array}{c}8 \\
(44.4 \%) \\
\end{array}$ & $\begin{array}{c}10 \\
(55.6 \%) \\
\end{array}$ & 18 \\
\hline $\begin{array}{r}\text { I conv } \\
\text { appr }\end{array}$ & $\begin{array}{c}0 \\
(0.0 \%)\end{array}$ & $\begin{array}{c}0 \\
(0.0 \%)\end{array}$ & $\begin{array}{c}7 \\
(38.9 \%)\end{array}$ & $\begin{array}{c}8 \\
(44.4 \%)\end{array}$ & $\begin{array}{c}3 \\
(16.7 \%)\end{array}$ & $\begin{array}{c}7 \\
(38.9 \%)\end{array}$ & $\begin{array}{c}11 \\
(61.1 \%)\end{array}$ & 18 \\
\hline $\begin{array}{r}\text { I do a } \\
\mathrm{i}\end{array}$ & $\begin{array}{c}0 \\
(0.0 \%) \\
\end{array}$ & $\begin{array}{c}0 \\
(0.0 \%) \\
\end{array}$ & $\begin{array}{c}3 \\
(16.7 \%) \\
\end{array}$ & $\begin{array}{c}9 \\
(50.0 \%) \\
\end{array}$ & $\begin{array}{c}6 \\
(33.3 \%) \\
\end{array}$ & $\begin{array}{c}3 \\
(16.7 \%) \\
\end{array}$ & $\begin{array}{c}15 \\
(83.3 \%) \\
\end{array}$ & 18 \\
\hline $\begin{array}{r}\text { I ask app } \\
\text { clarification } \\
\text { have no }\end{array}$ & $\begin{array}{c}0 \\
(0.0 \%)\end{array}$ & $\begin{array}{c}0 \\
(0.0 \%)\end{array}$ & $\begin{array}{c}4 \\
(22.2 \%)\end{array}$ & $\begin{array}{c}13 \\
(72.2 \%)\end{array}$ & $\begin{array}{c}1 \\
(5.6 \%)\end{array}$ & $\begin{array}{c}4 \\
(22.2 \%)\end{array}$ & $\begin{array}{c}14 \\
(77.8 \%)\end{array}$ & 18 \\
\hline $\begin{array}{c}\text { Multiple Responds Set } \\
\text { (MRS) }\end{array}$ & $\begin{array}{c}0 \\
(0.0 \%) \\
\end{array}$ & $\begin{array}{c}0 \\
(0.0 \%) \\
\end{array}$ & $\begin{array}{c}58 \\
(32.2 \%) \\
\end{array}$ & $\begin{array}{c}101 \\
(56.1 \%)\end{array}$ & $\begin{array}{c}21 \\
(11.7 \%)\end{array}$ & $\begin{array}{c}58 \\
(35.0 \%) \\
\end{array}$ & $\begin{array}{c}122 \\
(65.0 \%) \\
\end{array}$ & 180 \\
\hline
\end{tabular}

Table 3 above shows that during the pre-test in the experimental group, it was realized that less than the majority $35.0 \%$ of children had compliance skills and $65.0 \%$ lacked the skill. 
International Journal of Trend in Scientific Research and Development (IJTSRD) ISSN: 2456-6470

The indicator of compliance skills that children had skills the most was 'I play with my peers only at appropriate time' carrying a weight of $44.4 \%$.The indicator they lacked skills the most was "I cut off relations not wanted by my parents" with a weight of $5.6 \%$.

Table 4: pre-test assessment for compliance skills (control group)

\begin{tabular}{|c|c|c|c|c|c|c|c|c|}
\hline Compliance skills & lwa yc & the & $\begin{array}{l}\text { Some } \\
\text { times }\end{array}$ & Rarely & Jever & \multicolumn{2}{|c|}{ Collapse } & $\mathrm{N}$ \\
\hline Control g & & & & & & Present & AV & \\
\hline & $\begin{array}{l}0 \\
.0 \%) \\
\end{array}$ & $\begin{array}{c}1 \\
(5.6 \%) \\
\end{array}$ & $\begin{array}{c}4 \\
(22.2 \%) \\
\end{array}$ & $\begin{array}{c}13 \\
72.2 \%) \\
\end{array}$ & $\begin{array}{c}0 \\
(0.0 \%) \\
\end{array}$ & $\begin{array}{c}5 \\
(27.8 \%) \\
\end{array}$ & $\begin{array}{c}13 \\
(72.2 \%) \\
\end{array}$ & 18 \\
\hline $\begin{array}{c}\text { I do my ho } \\
\text { being }\end{array}$ & $\begin{array}{c}0 \\
0 \\
.0^{\circ} \\
\end{array}$ & $\begin{array}{c}0 \\
(0.0 \%) \\
\end{array}$ & $\begin{array}{c}6 \\
(33.3 \%) \\
\end{array}$ & $\begin{array}{c}12 \\
66.7 \%) \\
\end{array}$ & $\begin{array}{c}0 \\
(0.0 \%) \\
\end{array}$ & $\begin{array}{c}6 \\
(33.3 \%) \\
\end{array}$ & $\begin{array}{c}12 \\
66.7 \%)\end{array}$ & 18 \\
\hline $\begin{array}{r}\text { I lister } \\
\mathrm{c}\end{array}$ & $\begin{array}{l}0 \\
.0 \\
\end{array}$ & $\begin{array}{c}0 \\
(0.0 \%) \\
\end{array}$ & $\begin{array}{c}5 \\
(27.8 \%) \\
\end{array}$ & $\begin{array}{c}12 \\
66.7 \%) \\
\end{array}$ & $\begin{array}{c}1 \\
(5.6 \%) \\
\end{array}$ & $\begin{array}{c}5 \\
(27.8 \%) \\
\end{array}$ & $\begin{array}{c}13 \\
72.2 \%) \\
\end{array}$ & 18 \\
\hline $\begin{array}{r}\text { I comple } \\
\text { to }\end{array}$ & $\begin{array}{c}0 \\
(0.0 \%)\end{array}$ & $\begin{array}{c}0 \\
(0.0 \%)\end{array}$ & $\begin{array}{c}5 \\
(27.8 \%) \\
\end{array}$ & $\begin{array}{c}11 \\
(61.1 \%)\end{array}$ & 2 & $\begin{array}{c}5 \\
27.8 \%) \\
\end{array}$ & $\begin{array}{c}13 \\
(72.2 \%)\end{array}$ & 18 \\
\hline $\begin{array}{r}\text { I comple } \\
\text { or othe } \\
\text { in }\end{array}$ & $(0.0$ & $\begin{array}{r}0 \\
(0.0 \%\end{array}$ & $\begin{array}{c}6 \\
(33.3 \%)\end{array}$ & $(55.6 \%)$ & $\begin{array}{c}2 \\
(11.1 \%)\end{array}$ & $\begin{array}{c}6 \\
(33.3 \%)\end{array}$ & $\begin{array}{c}12 \\
(66.7 \%)\end{array}$ & 18 \\
\hline $\begin{array}{l}\text { I cu } \\
\text { want }\end{array}$ & $\begin{array}{c}0 \\
(0.0 \%)\end{array}$ & $\begin{array}{c}0 \\
(0.0 \%)\end{array}$ & $\begin{array}{c}6 \\
(33.3 \%)\end{array}$ & $\begin{array}{c}12 \\
(66.7 \%)\end{array}$ & $\begin{array}{c}0 \\
(0.0 \%)\end{array}$ & $\begin{array}{c}6 \\
(33.3 \%)\end{array}$ & $\begin{array}{c}12 \\
(66.7 \%)\end{array}$ & 8 \\
\hline $\begin{array}{r}\text { I play w } \\
\text { at ap }\end{array}$ & $\begin{array}{c}0 \\
(0.0 \%) \\
\end{array}$ & $\begin{array}{c}0 \\
(0.0 \%)\end{array}$ & $\begin{array}{c}5 \\
27.8 \%) \\
\end{array}$ & $\begin{array}{c}12 \\
(66.7 \%)\end{array}$ & $\begin{array}{c}1 \\
(5.6 \%)\end{array}$ & $\begin{array}{c}5 \\
(27.8 \%)\end{array}$ & $\begin{array}{c}13 \\
72.2 \%)\end{array}$ & 18 \\
\hline $\begin{array}{l}\text { I convers } \\
\text { approv }\end{array}$ & $\begin{array}{c}0 \\
(0.0 \%)\end{array}$ & $\begin{array}{c}0 \\
(0.0 \%)\end{array}$ & $(22.2 \%)$ & $\begin{array}{c}13 \\
(72.2 \%)\end{array}$ & $\begin{array}{c}1 \\
(5.6 \%)\end{array}$ & $\begin{array}{c}4 \\
(22.2 \%)\end{array}$ & $\begin{array}{c}14 \\
(77.8 \%)\end{array}$ & 8 \\
\hline $\begin{array}{l}\text { ents as } \\
\text { ed }\end{array}$ & $\begin{array}{c}0 \\
(0.0 \%)\end{array}$ & $\begin{array}{l}1 \\
5.6 \%)\end{array}$ & $\operatorname{lin}^{4} \mathrm{C}$ & $(61.1 \%)$ & $\begin{array}{c}2 \\
(11.1 \%)\end{array}$ & $\begin{array}{c}5 \\
(27.8 \%) \\
\end{array}$ & $\begin{array}{c}13 \\
(72.2 \%)\end{array}$ & 18 \\
\hline $\begin{array}{r}\text { I ask approp } \\
\text { clarification o } \\
\text { have not u }\end{array}$ & $\begin{array}{l}0 \\
(0.0 \%)\end{array}$ & $\left(5.6^{\circ}\right.$ & $\begin{array}{c}7 \\
(38.9 \%)\end{array}$ & $\begin{array}{c}10 \\
(55.6 \%)\end{array}$ & $\begin{array}{c}0 \\
(0.0 \%)\end{array}$ & $\begin{array}{c}8 \\
(44.4 \%)\end{array}$ & $\begin{array}{c}10 \\
(55.6 \%)\end{array}$ & 18 \\
\hline $\begin{array}{c}\text { Multiple Responds Set } \\
\text { (MRS) }\end{array}$ & $\begin{array}{c}0 \\
(0.0 \%) \\
\end{array}$ & $\begin{array}{c}3 \\
(1.7 \%) \\
\end{array}$ & $\begin{array}{c}52 \\
(28.9 \%)\end{array}$ & $\begin{array}{c}116 \\
(64.4 \%)\end{array}$ & $\begin{array}{c}9 \\
(5.0 \%)\end{array}$ & $\begin{array}{c}55 \\
(23.9 \%)\end{array}$ & $\begin{array}{c}125 \\
(76.1 \%)\end{array}$ & 180 \\
\hline
\end{tabular}

Table 4 above reveals that, during the pre-test in the control group, less than the majority (23.9\%) of children had compliance skills and $76.1 \%$ lacked compliance skills. The indicator of compliance skills lacked the most was 'I converse only in language approved by my parents" The indicator of compliance skills that children had the most was 'I asked appropriately for clarification of something not understood with a weight of $44.4 \%$

\section{Compliance skill assessment}

Parents perceived children to have $78.5 \%$ while the skills children had during the pre-test was $31.4 \%$. This means that there was a significant difference between the parents' perception and the compliance skills that children had during the pre-test. $\left(\chi^{2}=142.18 ; \mathrm{df}=1 ; \mathrm{P}<0.001\right)$.

Table 5: First formative assessment for Compliance skills

\begin{tabular}{|c|c|c|c|c|c|c|c|c|}
\hline Compliance skills & Always & $\begin{array}{l}\text { Most of } \\
\text { the time }\end{array}$ & Sometimes & Rarely & Never & \multicolumn{2}{|c|}{ Collapse } & $\mathbf{N}$ \\
\hline Experimental group & & & & & & Present & Absent & \\
\hline $\begin{array}{l}\text { I take to instructions } \\
\text { without complaining }\end{array}$ & $\begin{array}{c}0 \\
(0.0 \%)\end{array}$ & $\begin{array}{c}1 \\
(5.6 \%)\end{array}$ & $\begin{array}{c}16 \\
(88.9 \%)\end{array}$ & $\begin{array}{c}1 \\
(5.6 \%)\end{array}$ & $\begin{array}{c}0 \\
(0.0 \%)\end{array}$ & $\begin{array}{c}17 \\
(94.4 \%)\end{array}$ & $\begin{array}{c}1 \\
(5.6 \%)\end{array}$ & 18 \\
\hline $\begin{array}{c}\text { I do my home work } \\
\text { without being reminded }\end{array}$ & $\begin{array}{c}0 \\
(0.0 \%)\end{array}$ & $\begin{array}{c}6 \\
(33.3 \%)\end{array}$ & $\begin{array}{c}10 \\
(55.6 \%)\end{array}$ & $\begin{array}{c}2 \\
(11.1 \%)\end{array}$ & $\begin{array}{c}0 \\
(0.0 \%)\end{array}$ & $\begin{array}{c}16 \\
(88.9 \%)\end{array}$ & $\begin{array}{c}2 \\
(11.1 \%)\end{array}$ & 18 \\
\hline $\begin{array}{c}\text { I listen and carryout } \\
\text { directives }\end{array}$ & $\begin{array}{c}0 \\
(0.0 \%) \\
\end{array}$ & $\begin{array}{c}2 \\
(11.1 \%) \\
\end{array}$ & $\begin{array}{c}14 \\
(77.8 \%) \\
\end{array}$ & $\begin{array}{c}2 \\
(11.1 \%) \\
\end{array}$ & $\begin{array}{c}0 \\
(0.0 \%) \\
\end{array}$ & $\begin{array}{c}16 \\
(88.9 \%) \\
\end{array}$ & $\begin{array}{c}2 \\
(11.1 \%) \\
\end{array}$ & 18 \\
\hline $\begin{array}{l}\text { I complete any tasks } \\
\text { given to me on time }\end{array}$ & $\begin{array}{c}0 \\
(0.0 \%) \\
\end{array}$ & $\begin{array}{c}6 \\
(33.3 \%) \\
\end{array}$ & $\begin{array}{c}11 \\
(61.1 \%) \\
\end{array}$ & $\begin{array}{c}1 \\
(5.6 \%) \\
\end{array}$ & $\begin{array}{c}0 \\
(0.0 \%) \\
\end{array}$ & $\begin{array}{c}17 \\
(94.4 \%) \\
\end{array}$ & $\begin{array}{c}1 \\
(5.6 \%) \\
\end{array}$ & 18 \\
\hline
\end{tabular}


International Journal of Trend in Scientific Research and Development (IJTSRD) ISSN: 2456-6470

\begin{tabular}{|c|c|c|c|c|c|c|c|c|}
\hline $\begin{array}{l}\text { I complete my home } \\
\text { work or other assigned } \\
\text { tasks independently }\end{array}$ & $\begin{array}{c}1 \\
(5.6 \%)\end{array}$ & $\begin{array}{c}6 \\
(33.3 \%)\end{array}$ & $\begin{array}{c}5 \\
(27.8 \%)\end{array}$ & $\begin{array}{c}6 \\
(33.3 \%)\end{array}$ & $\begin{array}{c}0 \\
(0.0 \%)\end{array}$ & $\begin{array}{c}12 \\
(66.7 \%)\end{array}$ & $\begin{array}{c}6 \\
(33.3 \%)\end{array}$ & 18 \\
\hline $\begin{array}{l}\text { I cut off relations not } \\
\text { wanted by my parents }\end{array}$ & $\begin{array}{c}0 \\
(0.0 \%) \\
\end{array}$ & $\begin{array}{c}2 \\
(11.1 \%) \\
\end{array}$ & $\begin{array}{c}12 \\
(66.7 \%) \\
\end{array}$ & $\begin{array}{c}4 \\
(22.2 \%)\end{array}$ & $\begin{array}{c}0 \\
(0.0 \%) \\
\end{array}$ & $\begin{array}{c}14 \\
(77.8 \%) \\
\end{array}$ & $\begin{array}{c}4 \\
(22.2 \%) \\
\end{array}$ & 18 \\
\hline $\begin{array}{c}\text { I play with my peers } \\
\text { only at appropriate time }\end{array}$ & $\begin{array}{c}0 \\
(0.0 \%) \\
\end{array}$ & $\begin{array}{c}5 \\
(27.8 \%) \\
\end{array}$ & $\begin{array}{c}10 \\
(55.6 \%) \\
\end{array}$ & $\begin{array}{c}3 \\
(16.7 \%) \\
\end{array}$ & $\begin{array}{c}0 \\
(0.0 \%) \\
\end{array}$ & $\begin{array}{c}15 \\
(83.3 \%) \\
\end{array}$ & $\begin{array}{c}3 \\
(16.7 \%) \\
\end{array}$ & 18 \\
\hline $\begin{array}{l}\text { I converse only in } \\
\text { language approved by } \\
\text { my parents }\end{array}$ & $\begin{array}{c}0 \\
(0.0 \%)\end{array}$ & $\begin{array}{c}1 \\
(5.6 \%)\end{array}$ & $\begin{array}{c}15 \\
(83.3 \%)\end{array}$ & $\begin{array}{c}2 \\
(11.1 \%)\end{array}$ & $\begin{array}{c}0 \\
(0.0 \%)\end{array}$ & $\begin{array}{c}16 \\
(88.9 \%)\end{array}$ & $\begin{array}{c}2 \\
(11.1 \%)\end{array}$ & 18 \\
\hline $\begin{array}{l}\text { I do assignments as } \\
\text { instructed }\end{array}$ & $\begin{array}{c}0 \\
(0.0 \%)\end{array}$ & $\begin{array}{c}1 \\
(5.6 \%)\end{array}$ & $\begin{array}{c}12 \\
(66.7 \%)\end{array}$ & $\begin{array}{c}4 \\
(22.2 \%)\end{array}$ & $\begin{array}{c}1 \\
(5.6 \%)\end{array}$ & $\begin{array}{c}13 \\
(72.2 \%)\end{array}$ & $\begin{array}{c}5 \\
(27.8 \%)\end{array}$ & 18 \\
\hline $\begin{array}{l}\text { I ask appropriately for } \\
\text { clarification of } \\
\text { something I have not } \\
\text { understood }\end{array}$ & $\begin{array}{c}0 \\
(0.0 \%)\end{array}$ & $\begin{array}{c}6 \\
(33.3 \%) \\
\end{array}$ & $\begin{array}{c}10 \\
(55.6 \%)\end{array}$ & $\begin{array}{c}2 \\
(11.1 \%)\end{array}$ & $\begin{array}{c}0 \\
(0.0 \%)\end{array}$ & $\begin{array}{c}16 \\
(88.9 \%)\end{array}$ & $\begin{array}{c}2 \\
(11.1 \%)\end{array}$ & 18 \\
\hline $\begin{array}{c}\text { Multiple Responds Set } \\
\text { (MRS) }\end{array}$ & $\begin{array}{c}1 \\
0.6 \%) \\
\end{array}$ & $\begin{array}{c}36 \\
(20.0 \%)\end{array}$ & $\begin{array}{c}115 \\
(63.9 \%)\end{array}$ & $\begin{array}{c}27 \\
(15.0 \%)\end{array}$ & $\begin{array}{c}1 \\
(0.5 \%)\end{array}$ & $\begin{array}{c}152 \\
(84.4 \%)\end{array}$ & $\begin{array}{c}28 \\
(15.6 \%)\end{array}$ & 180 \\
\hline
\end{tabular}

Table 5 above shows that, during the first formative assessment, there was an improvement in all the indicators of compliance skills that the children had. Out of ten indicators of compliance skills, children improved in all. Children had $84.4 \%$ compliance skills and lacked just $15.6 \%$ skills. This indicated a great improvement from pre-test.

\section{Table 6: Second formative assessment for Compliance skills}

\begin{tabular}{|c|c|c|c|c|c|c|c|c|}
\hline Compliance skills & Always & $\begin{array}{l}\text { Most of } \\
\text { the time }\end{array}$ & $\begin{array}{l}\text { Some } \\
\text { times }\end{array}$ & Rarely & Never & \multicolumn{2}{|c|}{ Collapse } & $\mathbf{N}$ \\
\hline Experimental group & & & & & & Present & Absent & \\
\hline $\begin{array}{l}\text { I take to instructions without } \\
\text { complaining }\end{array}$ & $\begin{array}{c}1 \\
(5.6 \%)\end{array}$ & $\begin{array}{l}\text { Re } 14 \text { ea } \\
(77.8 \%)\end{array}$ & $\begin{array}{l}\text { Cr } 2 \text { aln } \\
(11.1 \%)\end{array}$ & $\begin{array}{c}1 \\
(5.6 \%)\end{array}$ & $\begin{array}{c}0 \\
(0.0 \%)\end{array}$ & $(94.4 \%)$ & $\begin{array}{c}1 \\
(5.6 \%)\end{array}$ & 18 \\
\hline $\begin{array}{l}\text { I do my assigned task without } \\
\text { being reminded }\end{array}$ & $\begin{array}{c}2 \\
(11.1 \%)\end{array}$ & $\begin{array}{c}14 \\
(77.8 \%)\end{array}$ & $\begin{array}{c}2 \\
(11.1 \%) \\
\end{array}$ & $\begin{array}{c}0 \\
(0.0 \%)\end{array}$ & $\begin{array}{c}0 \\
(0.0 \%)\end{array}$ & $\begin{array}{c}18 \\
(100.0 \%)\end{array}$ & $\begin{array}{c}0 \\
(0.0 \%)\end{array}$ & 18 \\
\hline I listen and carryout directives & $\begin{array}{c}2 \\
(11.1 \%)\end{array}$ & $\begin{array}{l}511 \% 2 \\
(61.1 \%)\end{array}$ & $\begin{array}{l}5654 \\
(27.8 \%)\end{array}$ & $\begin{array}{c}0 \\
(0.0 \%)\end{array}$ & $\begin{array}{c}0 \\
(0.0 \%)\end{array}$ & $\begin{array}{c}18 \\
(100.0 \%)\end{array}$ & $\begin{array}{c}0 \\
(0.0 \%)\end{array}$ & 18 \\
\hline $\begin{array}{l}\text { I complete any tasks given to } \\
\text { me on time }\end{array}$ & $\begin{array}{c}4 \\
(22.2 \%)\end{array}$ & $(61.1 \%)$ & $\begin{array}{c}3 \\
(16.7 \%)\end{array}$ & $\begin{array}{c}0 \\
(0.0 \%)\end{array}$ & $\begin{array}{c}0 \\
(0.0 \%)\end{array}$ & $\begin{array}{c}18 \\
(100.0 \%)\end{array}$ & $\begin{array}{c}0 \\
(0.0 \%)\end{array}$ & 18 \\
\hline $\begin{array}{c}\text { I complete my home work or } \\
\text { other assigned tasks } \\
\text { independently }\end{array}$ & $(33.3 \%)$ & $\begin{array}{c}9 \\
(50.0 \%)\end{array}$ & $(16.7 \%)$ & $(0.0 \%)$ & $(0.0 \%)$ & $\begin{array}{c}18 \\
(100.0 \%)\end{array}$ & $\begin{array}{c}0 \\
(0.0 \%)\end{array}$ & 18 \\
\hline $\begin{array}{l}\text { I cut off relations not wanted } \\
\text { by my parents }\end{array}$ & $\begin{array}{c}1 \\
(5.6 \%)\end{array}$ & $\begin{array}{c}11 \\
(61.1 \%)\end{array}$ & $\begin{array}{c}6 \\
(33.3 \%) \\
\end{array}$ & $\begin{array}{c}0 \\
(0.0 \%)\end{array}$ & $\begin{array}{c}0 \\
(0.0 \%)\end{array}$ & $\begin{array}{c}18 \\
(100.0 \%)\end{array}$ & $\begin{array}{c}0 \\
(0.0 \%)\end{array}$ & 18 \\
\hline $\begin{array}{l}\text { I play with my peers only at } \\
\text { appropriate time }\end{array}$ & $\begin{array}{c}2 \\
(11.1 \%)\end{array}$ & $\begin{array}{c}13 \\
(72.2 \%)\end{array}$ & $\begin{array}{c}3 \\
(16.7 \%)\end{array}$ & $\begin{array}{c}0 \\
(0.0 \%)\end{array}$ & $\begin{array}{c}0 \\
(0.0 \%)\end{array}$ & $\begin{array}{c}18 \\
(100.0 \%)\end{array}$ & $\begin{array}{c}0 \\
(0.0 \%)\end{array}$ & 18 \\
\hline $\begin{array}{l}\text { I converse only in language } \\
\text { approved by my teacher and } \\
\text { parents }\end{array}$ & $\begin{array}{c}1 \\
(5.6 \%)\end{array}$ & $\begin{array}{c}11 \\
(61.1 \%)\end{array}$ & $\begin{array}{c}5 \\
(27.8 \%)\end{array}$ & $\begin{array}{c}1 \\
(5.6 \%)\end{array}$ & $\begin{array}{c}0 \\
(0.0 \%)\end{array}$ & $\begin{array}{c}17 \\
(94.4 \%)\end{array}$ & $\begin{array}{c}1 \\
(5.6 \%)\end{array}$ & 18 \\
\hline I do assignments as instructed & $\begin{array}{c}2 \\
(11.1 \%) \\
\end{array}$ & $\begin{array}{c}12 \\
(66.7 \%) \\
\end{array}$ & $\begin{array}{c}4 \\
(22.2 \%) \\
\end{array}$ & $\begin{array}{c}0 \\
(0.0 \%) \\
\end{array}$ & $\begin{array}{c}0 \\
(0.0 \%) \\
\end{array}$ & $\begin{array}{c}18 \\
(100.0 \%) \\
\end{array}$ & $\begin{array}{c}0 \\
(0.0 \%) \\
\end{array}$ & 18 \\
\hline $\begin{array}{c}\text { I ask appropriately for } \\
\text { clarification of something I } \\
\text { have not understood }\end{array}$ & $\begin{array}{c}5 \\
(27.8 \%)\end{array}$ & $\begin{array}{c}10 \\
(55.6 \%)\end{array}$ & $\begin{array}{c}2 \\
(11.1 \%)\end{array}$ & $\begin{array}{c}1 \\
(5.6 \%)\end{array}$ & $\begin{array}{c}0 \\
(0.0 \%)\end{array}$ & $\begin{array}{c}17 \\
(94.4 \%)\end{array}$ & $\begin{array}{c}1 \\
(5.6 \%)\end{array}$ & 18 \\
\hline Multiple Responds Set (MRS) & $\begin{array}{c}26 \\
(14.4 \%)\end{array}$ & $\begin{array}{c}116 \\
(64.4 \%)\end{array}$ & $\begin{array}{c}35 \\
(19.4 \%)\end{array}$ & $\begin{array}{c}3 \\
(1.7 \%)\end{array}$ & $\begin{array}{c}0 \\
(0.0 \%)\end{array}$ & $\begin{array}{c}177 \\
(98.3 \%)\end{array}$ & $\begin{array}{c}3 \\
(1.7 \%)\end{array}$ & 180 \\
\hline
\end{tabular}


As seen from 6 above, during the second formative evaluation it was realised that there was an improvement in the skills acquired by the children from first formative to second formative assessment to $98.3 \%$. During this assessment children had acquired skills in all the indicators of compliance skills as all the indicators of compliance skills had weights of $100 \%$ except the indicators "I take to instructions without complaining, I converse only with language approved by my parents and teacher and I ask appropriately for clarification of something not understood with a weight of $94.4 \%$ each.

Table 7: Post-test assessment for compliance skills (experimental group)

\begin{tabular}{|c|c|c|c|c|c|c|c|c|}
\hline Compliance skills & lys & $\begin{array}{l}\text { M } \\
\text { the }\end{array}$ & tin & Rarely & Never & \multicolumn{2}{|c|}{ Collapse } & $\mathbf{N}$ \\
\hline Experimental group & & & & & & Pres & Ibse & \\
\hline $\begin{array}{r}\text { I take to ins } \\
\text { com }\end{array}$ & $\begin{array}{c}5 \\
7.8 \%\end{array}$ & $\begin{array}{r}10 \\
(55.6 \\
\end{array}$ & $\begin{array}{c}3 \\
(16.7 \%) \\
\end{array}$ & 0 & $\begin{array}{r}0 \\
\left(0.0^{\circ}\right. \\
\end{array}$ & $\begin{array}{c}18 \\
(100 \%)\end{array}$ & $\begin{array}{c}0 \\
0.0 \%) \\
\end{array}$ & 18 \\
\hline & 7 & $\begin{array}{c}10 \\
(55.6 \%) \\
\end{array}$ & $\begin{array}{c}1 \\
(5.6 \%) \\
\end{array}$ & 0 & ( & 18 & 0 & 18 \\
\hline I lister & $\begin{array}{c}7 \\
8.9 \%)\end{array}$ & $\begin{array}{c}10 \\
(55.6 \%)\end{array}$ & $\begin{array}{c}1 \\
(5.6 \%)\end{array}$ & $\begin{array}{c}0 \\
(0.0 \%)\end{array}$ & 0 & 1 & 0 & 18 \\
\hline $\begin{array}{r}\text { I complete } \\
\mathrm{m} \\
\end{array}$ & $\begin{array}{c}7 \\
(38.9 \%) \\
\end{array}$ & $\begin{array}{c}9 \\
(50.0 \%) \\
\end{array}$ & $\begin{array}{l}2 \\
(11.1 \%) \\
\end{array}$ & $\begin{array}{c}0 \\
(0.0 \%) \\
\end{array}$ & $\begin{array}{c}0 \\
(0.0 \%) \\
\end{array}$ & 18 & 0 & 18 \\
\hline $\begin{array}{r}\text { I complet } \\
\text { other } \\
\text { in } \\
\end{array}$ & $(55$. & $\begin{array}{c}7 \\
(38.9 \%)\end{array}$ & $\begin{array}{c}1 \\
(5.6 \%)\end{array}$ & $\begin{array}{c}0 \\
(0.0 \%)\end{array}$ & $\begin{array}{c}0 \\
(0.0 \%)\end{array}$ & $\begin{array}{c}18 \\
(100.0 \%)\end{array}$ & $\begin{array}{c}0 \\
(0.0 \%)\end{array}$ & 18 \\
\hline $\begin{array}{r}\text { I cut off } \\
b\end{array}$ & $\begin{array}{c}6 \\
(33.3 \%) \\
\end{array}$ & $\begin{array}{c}12 \\
(66.7 \%)\end{array}$ & $\begin{array}{c}0 \\
(0.0 \%) \\
\end{array}$ & $\begin{array}{c}0 \\
(0.0 \%)\end{array}$ & $(0.0 \%)$ & $(100$. & $\begin{array}{r}0 \\
0.0^{\circ}\end{array}$ & 18 \\
\hline $\begin{array}{r}\text { I play } \mathrm{w} \\
\mathrm{ap}\end{array}$ & $\begin{array}{c}9 \\
(50.0 \%)\end{array}$ & $\begin{array}{c}9 \\
(50.0 \%)\end{array}$ & $\begin{array}{c}0 \\
(0.0 \%)\end{array}$ & $\begin{array}{c}0 \\
(0.0 \%)\end{array}$ & $\begin{array}{c}0 \\
(0.0 \%)\end{array}$ & $\begin{array}{c}18 \\
(100.0 \%)\end{array}$ & 0 & 18 \\
\hline $\begin{array}{r}\text { I converse o } \\
\text { approved by }\end{array}$ & $\begin{array}{c}8 \\
(44.4 \%)\end{array}$ & $\begin{array}{c}8 \\
(44.4 \%)\end{array}$ & $(11.1 \%)$ & $\begin{array}{c}0 \\
(0.0 \%)\end{array}$ & $\begin{array}{c}0 \\
(0.0 \%)\end{array}$ & $\begin{array}{c}18 \\
(100.0 \%)\end{array}$ & $\begin{array}{c}0 \\
(0.0 \%)\end{array}$ & 18 \\
\hline $\begin{array}{l}\text { ents as } \\
\text { ed }\end{array}$ & $\begin{array}{c}12 \\
(66.7 \%) \\
\end{array}$ & $\begin{array}{c}6 \\
(33.3 \%) \\
\end{array}$ & $\begin{array}{c}0 \\
(0.0 \%) \\
\end{array}$ & $\begin{array}{c}0 \\
(0.0 \%) \\
\end{array}$ & $\begin{array}{c}0 \\
(0.0 \%) \\
\end{array}$ & $\begin{array}{c}18 \\
\left(100.0^{\circ}\right. \\
\end{array}$ & $\begin{array}{c}0 \\
0.0 \% \\
\end{array}$ & 18 \\
\hline $\begin{array}{r}\text { I ask a } \\
\text { clarificat } \\
\text { have }\end{array}$ & $\begin{array}{c}10 \\
(55.6 \%) \\
\end{array}$ & $\begin{array}{c}53 \\
(38.9 \%)\end{array}$ & $\begin{array}{l}56=64 \\
1(5.6 \%)\end{array}$ & $\begin{array}{c}0 \\
(0.0 \%) \\
\end{array}$ & $\begin{array}{c}0 \\
(0.0 \%)\end{array}$ & $\begin{array}{c}18 \\
\left(100.0^{\circ}\right.\end{array}$ & $\begin{array}{c}0 \\
(0.0 \%)\end{array}$ & 18 \\
\hline $\begin{array}{r}\text { Multiple R } \\
(\mathrm{M} \\
\end{array}$ & $\begin{array}{c}81 \\
(45.0 \%) \\
\end{array}$ & $\begin{array}{c}88 \\
(48.9 \%) \\
\end{array}$ & $\begin{array}{c}11 \\
(6.1 \%) \\
\end{array}$ & $\begin{array}{c}0 \\
(0.0 \%) \\
\end{array}$ & $\begin{array}{c}0 \\
(0.0 \%) \\
\end{array}$ & $\begin{array}{c}180 \\
(100.0 \%) \\
\end{array}$ & $\begin{array}{c}0 \\
(0.0 \%) \\
\end{array}$ & 180 \\
\hline
\end{tabular}

Table 7 above shows that, during the post-test assessment, all the children acquired all the indicators of compliance skills at $(100 \%)$ rate. This means that there was a great improvement from pre-test to post-test. For example, the indicators "I took to instruction without complaining, I converse only with language approved by my parents and teachers and I ask appropriately for clarification of something not understood moved from $94.4 \%$ to $100 \%$.

\section{Pre-test to post-test assessment for compliance skills}

There was a regular increase in the number of children that acquired the skills from pre-test to post-test. The percentage was $(32.2 \%)$ at pre-test, $(84.4 \%)$ at the first formative assessment, then increased to $(98.3 \%)$ at the second formative assessment and at post-test all the children had acquired the skills at a (100\%) rate. 
International Journal of Trend in Scientific Research and Development (IJTSRD) ISSN: 2456-6470

Table 8: Post-test assessment for compliance skills (control group)

\begin{tabular}{|c|c|c|c|c|c|c|c|c|}
\hline Compliance skills & Always & $\begin{array}{l}\text { Most of } \\
\text { the time }\end{array}$ & $\begin{array}{l}\text { Some } \\
\text { times }\end{array}$ & Rarely & Never & \multicolumn{2}{|c|}{ Collapse } & $\mathbf{N}$ \\
\hline Control group & & & & & & Present & Absent & \\
\hline $\begin{array}{l}\text { I take to instructions } \\
\text { without complaining }\end{array}$ & $\begin{array}{c}0 \\
(0.0 \%)\end{array}$ & $\begin{array}{c}1 \\
(5.6 \%)\end{array}$ & $\begin{array}{c}8 \\
(44.4 \%) \\
\end{array}$ & $\begin{array}{c}7 \\
(38.9 \%)\end{array}$ & $\begin{array}{c}2 \\
(11.1 \%)\end{array}$ & $\begin{array}{c}9 \\
(50.0 \%)\end{array}$ & $\begin{array}{c}9 \\
(50.0 \%) \\
\end{array}$ & 18 \\
\hline $\begin{array}{l}\text { I do my home work without } \\
\text { being reminded }\end{array}$ & $\begin{array}{c}0 \\
(0.0 \%)\end{array}$ & $\begin{array}{c}1 \\
(5.6 \%)\end{array}$ & $\begin{array}{c}4 \\
(22.2 \%)\end{array}$ & $\begin{array}{c}13 \\
(72.2 \%)\end{array}$ & $\begin{array}{c}0 \\
(0.0 \%) \\
\end{array}$ & $\begin{array}{c}5 \\
(27.8 \%)\end{array}$ & $\begin{array}{c}13 \\
(72.2 \%)\end{array}$ & 18 \\
\hline $\begin{array}{c}\text { I listen and carryout } \\
\text { directives }\end{array}$ & $\begin{array}{c}0 \\
(0.0 \%)\end{array}$ & $\begin{array}{c}0 \\
(0.0 \%)\end{array}$ & $\begin{array}{c}4 \\
(22.2 \%)\end{array}$ & $\begin{array}{c}13 \\
(72.2 \%)\end{array}$ & $\begin{array}{c}1 \\
(5.6 \%)\end{array}$ & $\begin{array}{c}4 \\
(22.2 \%)\end{array}$ & $\begin{array}{c}14 \\
(77.8 \%) \\
\end{array}$ & 18 \\
\hline $\begin{array}{l}\text { I complete any tasks given } \\
\text { to me on time }\end{array}$ & $\begin{array}{c}0 \\
(0.0 \%)\end{array}$ & $\begin{array}{c}0 \\
(0.0 \%)\end{array}$ & $\begin{array}{c}4 \\
(22.2 \%)\end{array}$ & $\begin{array}{c}12 \\
(66.7 \%)\end{array}$ & $\begin{array}{c}2 \\
(11.1 \%)\end{array}$ & $\begin{array}{c}4 \\
(22.2 \%)\end{array}$ & $\begin{array}{c}14 \\
(77.8 \%)\end{array}$ & 18 \\
\hline $\begin{array}{c}\text { I complete my home work } \\
\text { or other assigned tasks } \\
\text { independently }\end{array}$ & $\begin{array}{c}0 \\
(0.0 \%)\end{array}$ & $\begin{array}{r}0 \\
\left(0.0^{\circ}\right. \\
\end{array}$ & $\begin{array}{c}5 \\
(27.8 \%) \\
\end{array}$ & $\begin{array}{c}13 \\
(72.2 \%) \\
\end{array}$ & $\begin{array}{c}0 \\
(0.0 \%)\end{array}$ & $\begin{array}{c}5 \\
(27.8 \%)\end{array}$ & $\begin{array}{c}13 \\
(72.2 \%)\end{array}$ & 18 \\
\hline $\begin{array}{l}\text { I cut off relatic } \\
\text { wanted by my }\end{array}$ & $\begin{array}{c}0 \\
(0.0 \%)\end{array}$ & $\begin{array}{c}0 \\
(0.0 \%) \\
\end{array}$ & $\begin{array}{c}6 \\
(33.3 \%) \\
\end{array}$ & $\begin{array}{c}10 \\
(55.6 \%) \\
\end{array}$ & $\begin{array}{c}2 \\
(11.1 \%) \\
\end{array}$ & $\begin{array}{c}6 \\
(33.3 \%) \\
\end{array}$ & $\begin{array}{c}12 \\
(66.7 \%) \\
\end{array}$ & 18 \\
\hline $\begin{array}{r}\text { I play with my } \\
\text { at appropr }\end{array}$ & $\begin{array}{c}0 \\
(0.0 \%)\end{array}$ & $\begin{array}{c}0 \\
(0.0 \%)\end{array}$ & $\begin{array}{c}8 \\
(44.4 \%)\end{array}$ & $\begin{array}{c}10 \\
(55.6 \%)\end{array}$ & $\begin{array}{c}0 \\
(0.0 \%)\end{array}$ & $\begin{array}{c}8 \\
(44.4 \%) \\
\end{array}$ & $\begin{array}{c}10 \\
(55.6 \%) \\
\end{array}$ & 18 \\
\hline $\begin{array}{l}\text { I converse only in language } \\
\text { approved by my parents }\end{array}$ & $\begin{array}{c}0 \\
(0.0 \%)\end{array}$ & $\begin{array}{c}0 \\
(0.0 \%)\end{array}$ & $\begin{array}{c}5 \\
(27.8 \%) \\
\end{array}$ & $12(66.7 \%)$ & $1(5.6 \%)$ & $\begin{array}{c}5 \\
(27.8 \%)\end{array}$ & $\begin{array}{c}13 \\
(72.2 \%) \\
\end{array}$ & 18 \\
\hline $\begin{array}{l}\text { I do assignments as } \\
\text { instructed }\end{array}$ & $\begin{array}{c}0 \\
(0.0 \%)\end{array}$ & $\begin{array}{c}2 \\
(11.1 \%)\end{array}$ & $\begin{array}{c}4 \\
(22.2 \%)\end{array}$ & $\begin{array}{c}11 \\
(61.1 \%)\end{array}$ & 1 & $\begin{array}{c}6 \\
(33.3 \%)\end{array}$ & $\begin{array}{c}12 \\
(66.7 \%)\end{array}$ & 18 \\
\hline $\begin{array}{c}\text { I ask appropriately for } \\
\text { clarification of something I } \\
\text { have not understood }\end{array}$ & $\begin{array}{c}0 \\
(0.0 \%)\end{array}$ & $\begin{array}{l}2 \\
(11.1 \%)\end{array}$ & $\begin{array}{l}7 \\
(38.9 \%)\end{array}$ & $\begin{array}{c}9 \\
\text { e }(50.0 \%)\end{array}$ & $\begin{array}{c}0 \\
(0.0 \%)\end{array}$ & $(50.0 \%)$ & $\begin{array}{c}9 \\
(50.0 \%)\end{array}$ & 18 \\
\hline $\begin{array}{l}\text { Multiple Responds Set } \\
\text { (MRS) }\end{array}$ & $0(0.0 \%)$ & $\begin{array}{l}6 \% S \\
(3.3 \%) \\
\end{array}$ & $\begin{array}{c}55 \\
(30.6 \%) \\
\end{array}$ & $\begin{array}{l}110 \\
(61.1 \%) \\
\end{array}$ & $\begin{array}{c}9 \\
(5.0 \%) \\
\end{array}$ & $\begin{array}{c}61 \\
(33.9 \%) \\
\end{array}$ & $\begin{array}{c}119 \\
(66.1 \%)\end{array}$ & 180 \\
\hline
\end{tabular}

Above reveals that, in the control group, during the post test, less than the majority of the children $(33.9 \%)$ had compliance skills. The percentage of compliance skills lacked was $(66.1 \%$.) The indicators that children had $(50 \%)$ skills were "I take to instructions without complaining and I ask appropriately for clarification of something not understood". The rest of the indicators of compliance skills were below 50\% and the least indicators acquired were "I listen and carry out directives" and "I complete any task given to me on time" with weight of $22.2 \%$ each.



\section{Comparing between:}

Pre-test: $\chi 2$-test: $\chi 2=0.00 ; \mathrm{df}=1 ; \mathrm{P}=1.000$

Post-test: $\chi 2$-test: $\chi 2=18.00 ; \mathrm{df}=1 ; \mathrm{P}<0.001$

\section{Comparing within:}

Experimental group: $\chi 2=18.00 ; \mathrm{df}=1 ; \mathrm{P}<0.001$

Control group: $\chi 2=0.00 ; \mathrm{df}=1 ; \mathrm{P}=1.000$

\section{Discussions of findings}

The calculation of the cumulative progression of the second hypothesis showed that, the progression rate in the experimental group $(67.8 \%)$ between the pre-test and the post test was significantly higher than the progression rate in the control group (3.3\%). During the pre-test it was realised that children of the experimental group and the control group, partially 
had skills just for a few of the indicators that make up compliance skills. They lacked the skills of most of the indicators of compliance skills. The highest skills the children of the experimental group had before the treatment exercise was for the indicators "I complete task given to me on time and "I play with my peers only at appropriate time". While the skill children of the control group had highest was for the indicator "I ask appropriately for clarification of something not understood. During the first formative assessment, there was an improvement in all the indicators of compliance skills. Meaning that, the training given to children of the experimental group had a positive effect. The great improvement continued during the second formative assessment.

During the post test, it was discovered that all the children in the experimental group had acquired the skills of all the indicators of compliance skills. Children of the control group were still lacking in all the indicators of compliance skills during the post test. This clearly showed that the training given to children of the experimental group had a great impact. From the results, it was observed that a good number of children after the training, took to instructions without complaining, cut off relations not wanted by their teachers and parents, played with peers only at appropriate time and even conversed only in languages approved by their teachers and parents, did their assignment as instructed and without being reminded. The more they were appreciated the more they had interest in carrying out these activities. This actually showed a good sense of respect and responsibility. It was also observed that some of the children listened and carried out directives as instructed by the competent peers. As the children listened to, and responded to each other's ideas, they were able to reinforce their understandings thereby extending their cognitive and compliance skills. Therefore the alternative hypothesis which stated that Peer apprenticeship significantly influences the acquisition of compliance skills in children was upheld while the null hypothesis was rejected.

Furthermore, this result support the study conducted by Garton and Pratt, (2001) who concluded after their study that, children learned a lot from their peers. This is because they freely explain their ideas to others, collaborate, give and receive feedback and also evaluate their own learning. Through these, a lot of skills are developed. This is because when children work together, they challenge each other by offering alternative viewpoints which lead to the trying out of new ideas; a resolution of the conflict caused by contradictory views result in re-equilibration and new understanding.

\section{Concluding Statement}

Looking at the findings of this study, it is indicated that peer interaction influence the acquisition of social competence. This is seen through cooperative play, apprenticeship, collaborative activities and peer acceptance. It was also realized that peer interaction helps in the development of children's cultural beliefs and tradition. However, the study also proves that some of the children did not fully acquire certain aspects or indicators of the social competence during the first and second formative evaluation. For instance, some of them could not compromise with their friends, they complained before taking to instructions, conversed not in the language approved by their parents and teachers, felt reluctant to join in conversation with children they were not familiar with and also fails to show love to other children, thus a negative impact on their social competence. This was possible only during the post test assessment. This shows that some of the children needed a serious follow up before they could acquire the required social competences. That notwithstanding, majority of the children could control their emotions when hurt by others, resolved problems without consulting anybody, expressed needs and feelings appropriately, completed task given to them on time, did their assignments as instructed, listened to others' points of view, interacted with a variety of peers, took to instructions and corrections from other peers, understood the needs and desires of others and carried out activities courageously thus, a positive impact in the acquisition of their social competences.

The parental ethno theories surrounding peer relationships are evident from children's earliest infancy and continue to influence the company that children keep, the settings they occupy, and the activities that take up their time throughout middle childhood - a period that forecasts and prepares the child for future social roles. With increasing age, however, children's abilities to self-select become increasingly evident as their own preferences, proclivities, and scope for choice and control become emergent. Furthermore, their abilities to negotiate with socializing agents and even to resist socialization pressure also increase. The increasing importance of self-socialization processes is reflected not only in 
their noncompliance to adults but also in their interaction and relationships with peers. Clearly, who, how, and how much children interact with different social partners is influenced by the dynamics of individual characteristics and by contextual factors.

\section{References}

1. Belle, D. (1989). Gender differences in children's social networks and supports. In D. Belle (Ed.), Children's social networks and social supports (pp. 173-188). New York: Wiley

2. Berndt, T. J. \& Hoyle, S. G. (1985). Stability and change in childhood and adolescent friendships. Developmental Psychology, 21, 1007-1015.

3. Boyatzis, C. J. Mallis, M. \& Leon, I. (1999). Effects of game type on children's gender-based peer preferences: A naturalistic observational study. Sex Roles, 40, 93-105.

4. Buhrmester, D., \& Furman, W. (1987). The development of companionship and intimacy. Child Development, 58, 1101-1 113.

5. Feiring, C., \& Lewis, M. (1987). The child's social network: Sex differences from three to six years. Sex Roles, 17,621-636.

6. Feiring, C., \& Lewis, M. (1989). The social networks of girls and boys from early through middle childhood. In D. Belle (Ed.), Children's social networks and social supports (pp. 119-172). New York: Wiley.

7. Feiring, C., \& Lewis, M. (1991). The development of social networks from early to middle childhood: Gender differences and the relation to school competence. Sex Roles: A Journal of Research, 25,237-53.

8. Furman, W., \& Bierman, K. L. (1983). Developmental changes in young children's conceptions of friendship. Child Development, 54,549-556.

9. Gifford- Smith, M. E. and Brownell, C. A. (2008). Childhood peer relations: social acceptance, friendships, and peer net works. Journal of school psychology. 41,235-284.

10. Graham, J. A., Cohen, R., Zbikowski, S. M., \& Secrist, M. E. (1998). A longitudinal investigation of race and sex as factors in children's classroom friendship choices. Child Study Journal, 28,24527.
11. Harkness, S., \& Super, C. (Ms.). (1996). Parents' cultural belief systems (pp. 270-288). New York: Guilford.

12. Harkness, S., \& Super, C. M. (1985). The cultural context of gender segregation in children's peer groups. Child Development, 56,219-224.

13. Howes, C. \& Aikins, J. W. (2002). Peer relations in the transition to adolescence. Advances in Child Development and Behavior, 29, 195-230.

14. Jacklin, C. N., \& Maccoby, E. E. (1978). Social behavior at thirty-three months in same-sex and mixed-sex dyads. Child Development, 49,557569.

15. Maccoby, E. E. (1988). Gender as a social category. Developmental Psychology, 24, 755765. Maccoby, E. E. (1990). Gender and relationships. American Psychologist, 45,s 13520.

16. Maccoby, E. E. (1998). The two sexes: Growing up apart, coming together. Cambridge, MA: Bellknap Press.

17. Parke, R. and Buriel, R. (2006). Socialization in the family: Ethnic and ecological perspectives. In N. Eisenberg (Ed.), The handbook of child psychology: Social, emotional, and personality development (6th ed., Vol. 3, pp. 429-504). New York: Wiley.

18. Parker, J. G., and Asher, S.R. (1993). Beyond group acceptance: Friendship and friendship qualities as distinct dimensions of peer adjustment. In D. Perlman \& W. Jones (Eds.), Advances in personal relations. Found in


s \&source $=$ web \& cd=

19. Parker, J. G., Rubin, K. H., Erath, S. A., Wojslawowicz, J. C. and Buskirk, A. A. (2015) Peer Relationships, Child Development, and Adjustment: A Developmental Psychopathology Perspective, in Developmental Psychopathology, Second Edition (eds) Cicchetti, D. and Cohen, J. D, Wiley, J. and Sons, Inc., Hoboken, NJ, USA. doi: $10.1002 / 9780470939383 . c h 12$

20. Pitcher, E. G., \& Schultz, L. H. (1983). Boys and girls at play: The development of sex roles. New York: Bergin \& Garvey.

21. Rogoff, B. (1990). Apprenticeship in thinking: Cognitive development in social context. New York: Oxford University Press. 
22. Rogoff, B. (1992). Three ways to relate person and culture: Thoughts sparked by Valsiner's review of Apprenticeship in Thinking. Human Development. 35, 316-320.

23. Rogoff, B. (1993). Children's guided participation and participatory appropriation in sociocultural activity. In R. Woxniak K. Fischer (Eds.), Development in context: Acting and thinking in specific environments (pp. 121-153). Hillsdale, NJ: Erlbaum.

24. Rogoff, B., (1984). Thinking and learning in a social context. In B. Rogoff \& J. Lave (Eds.) Everyday cognition- its development in social context (pp:1-8) Cambridge, Massachusetts: Harvard University Press.

25. Rubin, K. H., Bukowski, W.M., Laursen, B. P. (2009), Handbook peer interactions, relations, and groups. New York: The Guilford Press.

26. Rubin, K. H., Bukowski, W., \& Parker, J. G. (1998). Peer interactions, relationships, and groups. In N. Eisenberg (Vol. Ed.), Handbook of child psychology: Social and personality development (Vol. 3, pp. 619-700). New York: Wiley.

27. Rubin, K. H., Bukowski, W., and Parker, J. G. (1998). Peer interactions, relationships, and groups. In W. Damon (Series Ed.) \& N. Eisenberg (Eds), Handbook of child psychology: Vol. 3. Social, emotional, and personality development (5th ed). New York: Wiley.

28. Rubin, K. H., Fein, G., \& Vandenberg, B. (1983). Play. In P. H. Mussen (Series Ed.) and E. M. Hetherington (Vol. Ed.), Handbook of child psychology: Vol. 4. Socialization, personality and social development (4th ed., pp. 693-774). New York: Wiley.
29. Serpell, R (2011). Peer Group Cooperation as a Resource for Promoting Socially Responsible Intelligence. In Nsamenang, A. B., and Tchombe, T.M.S (2011). Handbook of African Educational Theories \& practices: A generative teacher Education Curriculum. Bamenda: Human Development Resource Centre.

30. Sert, A, G. (2003). The Effect of an Assertiveness Training on the Assertiveness and Self Esteem Level of $5^{\text {th }}$ Grade Children. Master Thesis.

31. Skinner, B.F (1954). The science of learning and the art of teaching, Harvard Educational Review

32. Tudge, J. \& Hogan, D. (2005). An ecological approach to naturalistic observation. In S. M. Greene \& D. M. Hogan (Eds.), Researching children's experiences: Approaches and methods (pp. 102-121). London: Sage.

33. Tudge, J. R. H., Hogan, D. M., Lee, S., Meltsas, M., Tarnmeveski, P., Kulakova, N. N., et al. (1999). Cultural heterogeneity: Parental values and beliefs and their preschoolers' activities in the United States, South Korea, Russia, and Estonia. In A. Goncu (Ed.), Children's engagement in the world, (pp. 62-96). New York: Cambridge University Press.'

34. Tudge, J., Hayes, S., Doucet, F., Odero, D. Kulakova, N., Tammeveski, P., et al. (2000). Parents' participation in cultural practices with their preschoolers. Psicologia: Teoria e Pesquisa, $16,1-10$. 